\title{
Disinfection of Dental Chair Water Using Aqueous Chlorine Dioxide
}

\author{
Li-Lin Wei ${ }^{1, *}$, Chan-Chih Hu ${ }^{2}$, Chu-Wei Hsu ${ }^{3}$, Chun-Wei Pen ${ }^{3}$, Li-Yu Chen ${ }^{4}$, Yu-Chun Yu ${ }^{5}$, James R. Carey ${ }^{6}$, \\ Hao-Chang Yin ${ }^{3}$ and Shan-Shue Wang ${ }^{3, *}$ (1)
}

1 Lian Medical Protection Equipment Co., Ltd., Kaohsiung 813328, Taiwan

2 Guangdong ZD Aquatic Environmental Technology Co., Ltd., Zhongshan 528411, China; cypressj@hotmail.com

3 Department of Cosmetology and Health Care, Kao Yuan University, Kaohsiung 821013, Taiwan; wei751001@gmail.com (C.-W.H.); f08220927@gmail.com (C.-W.P.); pigart123@gmail.com (H.-C.Y.)

4 Undergraduate program of Electro-Optical Engineering, National Taiwan Normal University, Taipei 10610, Taiwan; ellechenyin89@gmail.com

5 Baihui Mercury Environmental Technology (Beijing) Co., Ltd., Beijing 100144, China; jamesyu1204@163.com

6 Ace Glass, Inc., Vineland, NJ 08360, USA; biocatalysis@gmail.com

* Correspondence: woodywei56@gmail.com (L.-L.W.); sswang168@gmail.com (S.-S.W.)

Citation: Wei, L.-L.; Hu, C.-C.; Hsu, C.-W.; Pen, C.-W.; Chen, L.-Y.; Yu, Y.-C.; Carey, J.R.; Yin, H.-C.; Wang, S.-S. Disinfection of Dental Chair Water Using Aqueous Chlorine Dioxide. Water 2021, 13, 3442. https://doi.org/10.3390/w13233442

Academic Editors: Efthimia A. Kaprara and Jiangyong $\mathrm{Hu}$

Received: 15 October 2021

Accepted: 2 December 2021

Published: 4 December 2021

Publisher's Note: MDPI stays neutral with regard to jurisdictional claims in published maps and institutional affiliations.

Copyright: (c) 2021 by the authors. Licensee MDPI, Basel, Switzerland. This article is an open access article distributed under the terms and conditions of the Creative Commons Attribution (CC BY) license (https:// creativecommons.org/licenses/by/ $4.0 /)$.

\begin{abstract}
Chlorine dioxide is a safe, environmentally friendly disinfecting agent. In this study, aqueous chlorine dioxide (ACD) was used to improve the water quality of dental chairs. However, chlorine dioxide is readily released from ACD solutions under open atmosphere conditions. Described herein is a water purification and disinfection system using ACD. The system was designed, fabricated, and integrated into an existing dental chair water system. This system is referred to as an ACD dental chair. Because $\mathrm{ClO}_{2}$ readily degasses from ACD, there needs to be a way to maintain and measure the ACD solution in real time. In our studies, we found that $\mathrm{pH}$ and oxidation-reduction potential (ORP) change as a function of chlorine dioxide concentration and are easily controlled and measured. The dosing of the ACD was designed to begin at $800 \mathrm{mV}$ and stop dosing at $810 \mathrm{mV}$ in the ACD dental chair. Through use of this continuous monitoring and automatic dosing system, the water ORP was controlled between 800 and $860 \mathrm{mV}$. This range is the effective concentration of chlorine dioxide that is without chlorine-like odor and microorganism growth. The ACD dental chair controlled the total bacterial count to $<5 \mathrm{CFU} / \mathrm{mL}$ and the chlorite concentration was less than $0.0004 \mathrm{mg} / \mathrm{L}$, meeting legal standards of Taiwan, the USA, and China. In addition to the application of ACD in dental chairs, it may also be used in closed water systems for food, cosmetics, beverages, and other industries.
\end{abstract}

Keywords: chlorine dioxide; ORP; automatic monitoring and management; hygiene

\section{Introduction}

Infection prevention when treating oral diseases in dental patients is an important and difficult task. Infection during dental treatment can come from a variety of sources and materials, including equipment and treatment water used in clinical practice [1]. Hence, a clean environment and water source are basic requirements. Preventative measures include personnel protective measures, disinfection and sterilization of non-disposable instruments, and management and monitoring of water sources for the treatment chairs. Among all infection sources, the water sources used during dental treatments is easily ignored and difficult to manage [2]. The water supply pipeline to the dental chair is usually narrow and difficult to clean. When the clinic is closed, the water in the pipeline is stagnated because the dental chair is not in use. In this situation, bacteria have the opportunity to attach to the water piping walls and initiate cell growth. Bacteria are able to grow and form biofilms after a long period of time. As the biofilm grows to a certain size, bacteria are gradually released into the water, becoming a source of infection [3]. The aerosol and 
splatter generated with contaminated water by the dental chair hand pieces could also pose a risk for both dental personnel and patients [4]. The water source cannot easily be examined because the water pipeline is deeply buried in the dental chair. Unless the water produces a visible suspension or sediment, bacterial contamination is not easy to detect.

Reverse osmosis (RO) water is often used as a water source in Taiwan's dental hospitals and clinics. $\mathrm{RO}$ water is usually sterile because the bacteria is removed through filtering. However, the RO water supply tank can become contaminated with bacteria. Due to stagnation in the pipeline when the clinic is closed, bacteria can grow in the supply water tank or water pipeline. Although regular cleaning, disinfection, and monitoring of water quality are currently performed manually in dental clinics, there are still many water management defects that can cause the water to be contaminated.

In order to achieve an effective aseptic environment and improve water management and quality, we chose ACD as the disinfectant. ACD was chosen in part due to its environmental friendliness. We developed an automatic detection and disinfection system using $\mathrm{ACD}$ for improving the quality of water from dental chairs (referred to as the ACD dental chair). The ACD is maintained at a specified concentration range of chlorine dioxide in the water supply piping system to prevent bacteria growth and maintain a sterile state.

Chlorine dioxide $\left(\mathrm{ClO}_{2}\right)$ is an extremely active oxidizing gas with a boiling point of $11{ }^{\circ} \mathrm{C}$ and a melting point of $-59{ }^{\circ} \mathrm{C}$ [5]. Gaseous $\mathrm{ClO}_{2}$ is not easily preserved at room temperature, and it is quickly decomposed into chlorine and oxygen in the air [6]. $\mathrm{ClO}_{2}$ is highly soluble in neutral or near neutral water. Under these conditions, $\mathrm{ClO}_{2}$ is relatively stable and retains its high oxidizing power [5]. ACD can efficiently remove bacteria, fungi, and viruses in the environment [7-12]. In contrast, higher concentrations of $\mathrm{ClO}_{2}$ are harmful to human cells ( $\mathrm{IC}_{50} 765 \pm 18 \mathrm{ppm}$ ) [10]. Chronic exposure of $\mathrm{ClO}_{2}$ and its byproducts (chlorite and chlorate) present no clinically physiological effects [13-15]. $\mathrm{ClO}_{2}$ can remove biofilms from water pipes [16,17] and stainless steel [18].

When ACD is implemented as a disinfectant, the gaseous $\mathrm{ClO}_{2}$ oxidizes and inactivates bacteria, fungi, and viruses. The gaseous $\mathrm{ClO}_{2}$ molecules in water easily escape into the atmosphere, reducing the gaseous $\mathrm{ClO}_{2}$ concentration in the water. Hence, after treatment and a specified amount of time, the gaseous chlorine dioxide molecules reduce or disappear in water and decrease its cleaning power. In order to improve this shortcoming, gaseous $\mathrm{ClO}_{2}$ molecules must be maintained to a certain effective concentration in the water, so that the effect of gaseous $\mathrm{ClO}_{2}$ molecules can be sustained. We developed a system where $A C D$ is used in conjunction with several devices to achieve a continuous effective $\mathrm{ClO}_{2}$ concentration. The ACD dental chair achieves the cleanliness of regulation standards and solves the problem of improper water management.

In this study, the ACD dental chair was designed, fabricated, and studied. The effective concentration of $\mathrm{ClO}_{2}$ can be maintained in the ACD dental chair system to clean the water and keep it in a sterile state. In addition to the application of ACD in dental systems, this new system may also be implemented in the water control of closed pipeline systems, such as food and cosmetic factories.

\section{Materials and Methods}

\subsection{Materials}

$\mathrm{ClO}_{2}$ aqueous solutions were obtained from Guangdong ZD Aquatic Environmental Technology Co., Ltd, Zhongshan 528411, China. The water purification and disinfectant system, composed of a control unit, sensing unit, dosing unit, and mixed disinfectant water supply unit were provided by Lian Medical Protection Equipment Co., Ltd., Kaohsiung 813328, Taiwan. DPD1 reagent solution M and DPD1 buffer solution were purchased from ProMinent Fluid Controls, Inc., Im Schuhmachergewann 5-11, Heidelberg 69123, German.

\section{2. $\mathrm{ClO}_{2}$ Measurement}

DPD1 is a mixture containing sulfuric acid (5-10\%) and N,N-diethyl-14-phenylenediamine sulfate $(2.5 \%)$. Two drops of DPD1 reagent solution M (ProMinent, Im Schuhmacherge- 
wann 5-11, Heidelberg 69123, German) are mixed with six drops of DPD1 buffer solution (ProMinent). Next, $10 \mathrm{~mL}$ of ACD of various concentrations was added, mixed, and measured using a DT1B Photometer (ProMinent).

\subsection{Oxidation Reduction Potential (ORP) Measurement}

Aqueous solutions of various $\mathrm{ClO}_{2}$ concentrations $(0,5,10,25,50,100,200 \mathrm{ppm})$ were prepared by $2000 \mathrm{ppm}$ ACD diluted with RO water. The ORP6041 detector (CLEAN Instruments Co., LTD., New Taipei 23570, Taiwan) was calibrated using standardized solutions. The various concentrations of ACD were then determined its ORP using data produced by the ORP6041 detector.

\section{4. $\mathrm{pH}$ Measurement}

Aqueous solutions of various $\mathrm{ClO}_{2}$ concentrations $(0,5,10,25,50,100,200 \mathrm{ppm})$ were prepared by 2000 ppm ACD diluted with $\mathrm{RO}$ water. The $\mathrm{pH} 30$ detector (Chi Jui Instrument Enterprise CO., LTD., Taichung City 40254, Taiwan) was calibrated using standardized solutions. The $\mathrm{pH}$ values of various concentrations of $\mathrm{ACD}$ were determined using a $\mathrm{pH} 30$ detector.

\subsection{Chlorine-like Odor Measurement}

The characteristic pungent chlorine-like odor of ACD comes from $\mathrm{ClO}_{2}$. The testing subject took $10 \mathrm{~mL}$ of different pipeline water sources containing various concentrations of $\mathrm{ClO} 2$ into the mouth for $30 \mathrm{~s}$. The subject then immediately indicated the chlorine-like odor on a scale from 0 to 3; 1-very weak chlorine-like odor, 2-slight chlorine-like odor, and 3 - strong chlorine-like odor. Each test had 20 replicates.

\subsection{Chlorite Measurement}

The chlorite measurement method was detailed in a previous report [19]. One milliliter phosphate buffer ( $\mathrm{pH} 7.0$ ) was added into $200 \mathrm{~mL}$ water samples in a special bottle. The bottle was connected to a well-sealed pipeline and aerated with nitrogen for $15 \mathrm{~min}$. One gram of potassium iodide was added while stirring and titrating with sodium thiosulfate to the end point. To this solution was added $2 \mathrm{~mL}$ of $2.5 \mathrm{~N}$ hydrochloric acid, which was then left to stand in the dark for $5 \mathrm{~min}$, and sodium thiosulfate was titrated to the end point.

$$
\text { Chlorite concentration }=\mathrm{D} \times \mathrm{N} \times 16,863
$$

D: Number of mL of sodium thiosulfate titration; $\mathrm{N}$ : Equivalent concentration of sodium thiosulfate.

\subsection{Total Bacteria Measurement}

$\mathrm{RO}$ water samples (undiluted) were evenly smeared on a Petri dish ( $1 \mathrm{~g}$ glucose, $5 \mathrm{~g}$ tryptone, $2.5 \mathrm{~g}$ yeast extract, $15 \mathrm{~g}$ agar $/ 1000 \mathrm{~mL} \mathrm{H}_{2} \mathrm{O}$ ) (Xinxin Chemical, Tainan 70169, Taiwan) and placed in a $35 \pm 1{ }^{\circ} \mathrm{C}$ incubator for $48 \mathrm{~h}$. Between 30 to 300 bacteria colonies were observed and counted. The detection limit is $<5 \mathrm{CFU} / \mathrm{mL}$.

\section{8. $\mathrm{ClO}_{2}$ Aqueous Solution Application in Dental Clinics}

The ACD was setup in 12 dental clinics where the water purification and disinfectant system was integrated into the dental chair. The water ORP was monitored and total bacteria of water were examined before and after installation.

\section{Results and Discussion}

\subsection{Water Purification and Disinfectant System}

The ACD dental chair includes an RO water filter appliance, control unit, sensing unit, dosing unit, and mixed disinfectant water supply unit (Figure 1). The ACD was stored in the dosing unit. The water ORP was measured by the ORP sensor of the ORP sensing unit and output the ORP value on the display. The dosing unit ORP was set at $800 \mathrm{mV}$ to begin dosing and $810 \mathrm{mV}$ to stop dosing. The ORP sensor can automatically measure the ORP 
value of the mixed disinfectant water supply unit and display it on the screen. When the ORP of the water quality drops to $800 \mathrm{mV}$, the ORP sensing unit informs the control unit, and the control unit gives instructions to require the dosing unit to administer the ACD to the water body of the mixing chamber. When the ORP sensor automatically detects that the ORP rises to $810 \mathrm{mV}$, it notifies the control unit, and the control unit gives instruction to the dosing unit to stop dosing the ACD.

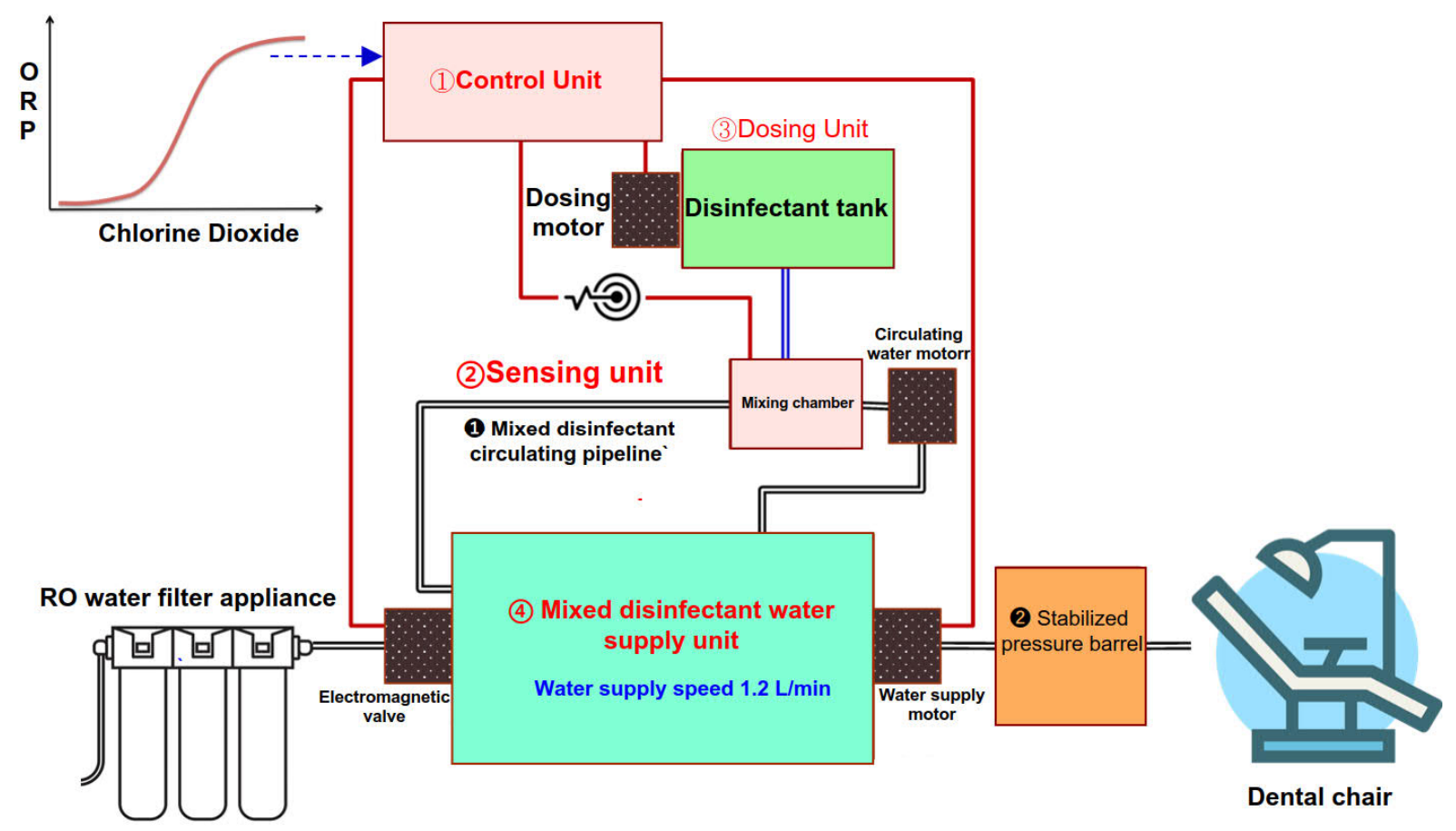

Figure 1. ACD dental chair including control unit, ORP sensing unit, disinfectant dosing unit, and mixed disinfectant water supply unit.

\section{2. $\mathrm{ClO}_{2}$ Concentration in $\mathrm{ACD}$ and $\mathrm{pH}$}

Aqueous solutions of various $\mathrm{ClO}_{2}$ concentrations $(0,5,10,25,50,100,200 \mathrm{ppm})$ were tested using a pH meter. The relationship between the $\mathrm{ClO}_{2}$ concentration of the ACD and $\mathrm{pH}$ is shown in Figure 2. The higher the concentration of $\mathrm{ClO}_{2}$ in water, the lower the $\mathrm{pH}$. The $\mathrm{pH}$ of $\mathrm{RO}$ water is approximately 6.0 at $25^{\circ} \mathrm{C}$. When $\mathrm{ClO}_{2}$ was added, the $\mathrm{pH}$ value dropped rapidly. The $\mathrm{pH}$ was 3.62 at $25 \mathrm{ppm}$ and 2.65 at $200 \mathrm{ppm}$, showing high acidity. In general, microorganism growth was inhibited when the $\mathrm{pH}$ is less than 4.

\section{3. $\mathrm{ClO}_{2}$ Concentration in $\mathrm{ACD}$ and $\mathrm{ORP}$}

Aqueous solutions of various $\mathrm{ClO}_{2}$ concentrations $(0,5,10,25,50,100,200 \mathrm{ppm})$ were tested using an ORP meter. The relationship between the $\mathrm{ClO}_{2}$ concentration of the ACD and the ORP is shown in Figure 3. The higher the concentration of $\mathrm{ClO}_{2}$, the higher the ORP value. The ORP of RO pure water is approximately $250 \pm 10 \mathrm{mV}$. When $\mathrm{ClO}_{2}$ was added, the ORP rose rapidly. Above $25 \mathrm{ppm}$, the ORP rose slowly. The ORP at $10 \mathrm{ppm}$ $\mathrm{ClO}_{2}$ reached $820 \mathrm{mV}$ or more. The ACD at 0.1-10 ppm and 20-50 ppm can destroy most bacteria and fungi, respectively [10]. 


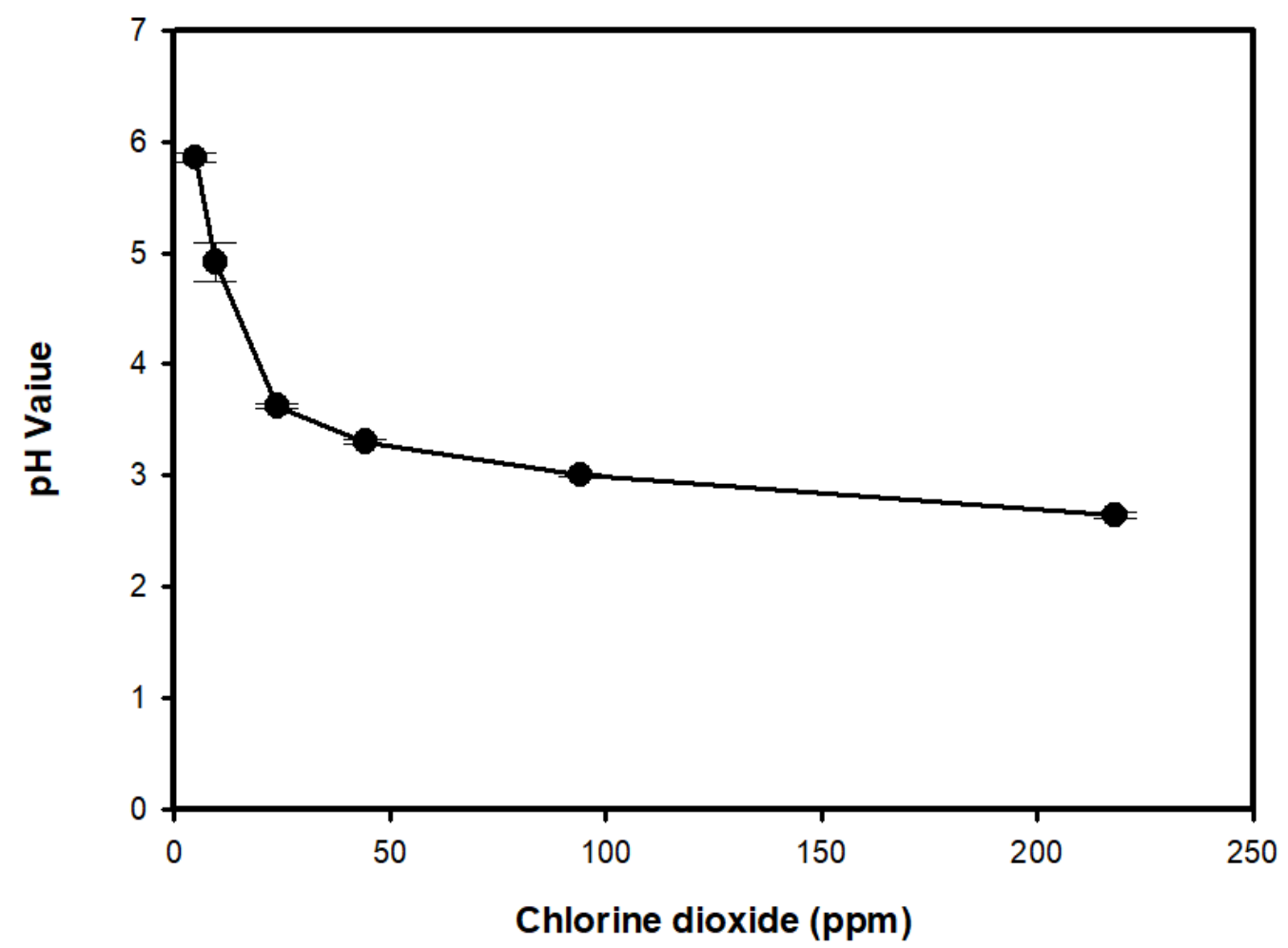

Figure 2. The relationship between the $\mathrm{ClO}_{2}$ concentration of $\mathrm{ACD}$ and $\mathrm{pH}$ in water.

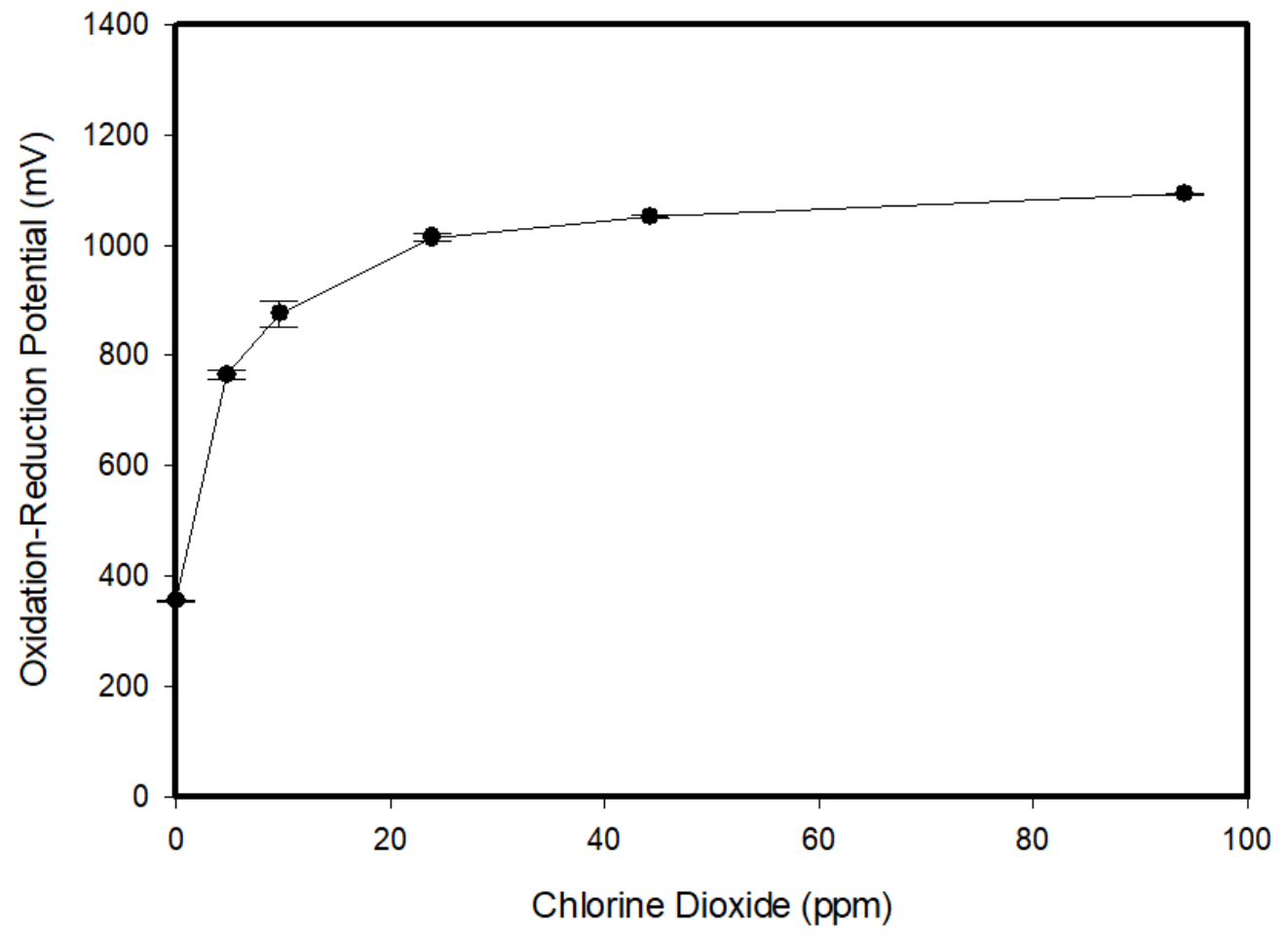

Figure 3. The relationship between the $\mathrm{ClO}_{2}$ concentration of ACD and ORP in water.

3.4. Dosing Disinfectant between 800 and $900 \mathrm{mV}$ ORP

3.4.1. ORP and Chlorine-like Odor of Water in an Open System

The $800 \mathrm{mV}$ water (ORP at initiation) was prepared by adding $2.5 \mathrm{~mL}$ of $2000 \mathrm{ppm}$ $\mathrm{ClO}_{2}$ to $1 \mathrm{~L}$ of $\mathrm{RO}$ water. The $800 \mathrm{mV}$ ORP solution was then filled with $2000 \mathrm{ppm}$ ACD and dosing was stopped at the indicated specific ORP, as shown in Table 1 (ORP at stop). After ACD dosing was stopped, the water ORP continued to rise and then stopped at specific 
values given in Table 1 (ORP at stabilization). Hence, the table demonstrates ORP at stop and ORP at stabilization. The chlorine-like odor of ORP at stabilization was examined. There was no odor found in the ACD when the ORP was below $860 \mathrm{mV}$. However, when the ORP value reached more than $860 \mathrm{mV}$, a chlorine-like odor emerged. The solution had a very weak chlorine-like odor when the ORP value was between 863 and $874 \mathrm{mV}$, a slight chlorine-like odor when the ORP was between 885 and $893 \mathrm{mV}$, and a strong chlorine-like odor when the ORP was between 898 and $901 \mathrm{mV}$.

Table 1. Chlorine-like odor at 801-896 mV ORP of dosing stop in open system.

\begin{tabular}{ccc}
\hline $\begin{array}{c}\text { ORP at Stop } \\
(\mathbf{m} \mathbf{)})\end{array}$ & $\begin{array}{c}\text { ORP at Stabilization } \\
(\mathbf{m} \mathbf{)})\end{array}$ & Chlorine-Like Odor \\
\hline 801 & 811 & 0 \\
810 & 818 & 0 \\
820 & 826 & 0 \\
830 & 837 & 0 \\
840 & 844 & 0 \\
850 & 853 & 0 \\
860 & 863 & 1 \\
870 & 874 & 1 \\
880 & 885 & 2 \\
890 & 893 & 2 \\
895 & 898 & 3 \\
896 & 901 & 3 \\
\hline
\end{tabular}

The initial values of the ORP were found to be $800 \mathrm{mV}$. The ORP was increased by slow addition of a $2000 \mathrm{ppm}$ of $\mathrm{ClO}_{2}$ in water.

\subsubsection{ORP and Chlorine-like Odor of Water in a Closed-Tube System}

The prototype closed-tube system included a control unit, ORP sensing unit, disinfectant dosing unit, and an $18 \mathrm{~L}$ mixed water supply unit. In order to maintain the $800 \mathrm{mV}$ ORP of water in a closed-tube system, the $2000 \mathrm{ppm}$ ACD under $1.2 \mathrm{~L} / \mathrm{min}$ water supply was dosed into the water system when the water ORP was less than $800 \mathrm{mV}$. When the ORP sensor detected $801,805,810 \mathrm{mV}$, the dosing of the ACD was stopped and the water supply continued to circulate. The ORP was stable at $826,838,854 \mathrm{mV}$, respectively. Under these conditions, no chlorine-like odor was found (Table 2). Therefore, the control system was set to start dosing at $800 \mathrm{mV}$ and stop dosing at $810 \mathrm{mV}$. When the ORP sensor sensed $810 \mathrm{mV}$, the dosing was stopped, and the water supply continued to circulate. The ORP stabilized at $854 \mathrm{mV}$. The chlorine-like odor began to appear as the ORP reached above $860 \mathrm{mV}$. Therefore, the setting to achieve a stable ORP is where it does not exceed $860 \mathrm{mV}$.

Table 2. Chlorine-like odor at 801-810 mV ORP of dosing stop in closed-tube system.

\begin{tabular}{ccc}
\hline ORP at Dosing Stop $(\mathbf{m V})$ & $\begin{array}{c}\text { ORP at Stabilization } \\
(\mathbf{m V})\end{array}$ & Chlorine-Like Odor \\
\hline 801 & 826 & 0 \\
805 & 838 & 0 \\
810 & 854 & 0 \\
\hline
\end{tabular}

Note 1:0- no chlorine-like odor.

\subsubsection{Automatic Monitoring of Water ORP by Dosing ACD in a Closed-Tube System}

A chlorine-like odor was detected when the water ORP reached above $860 \mathrm{mV}$. Therefore, the control system was set to start dosing at $800 \mathrm{mV}$ and stop dosing at $810 \mathrm{mV}$. When the ORP sensor detected $810 \mathrm{mV}$, the dosing was stopped and the water supply continued to circulate until the ORP stabilized at $854 \mathrm{mV}$. Figure 4 shows the actual experimental curve of water ORP monitored at 800 and $810 \mathrm{mV}$ in the closed-tube system, confirming that the system can control the water ORP between $800-860 \mathrm{mV}$ with appropriate settings. 


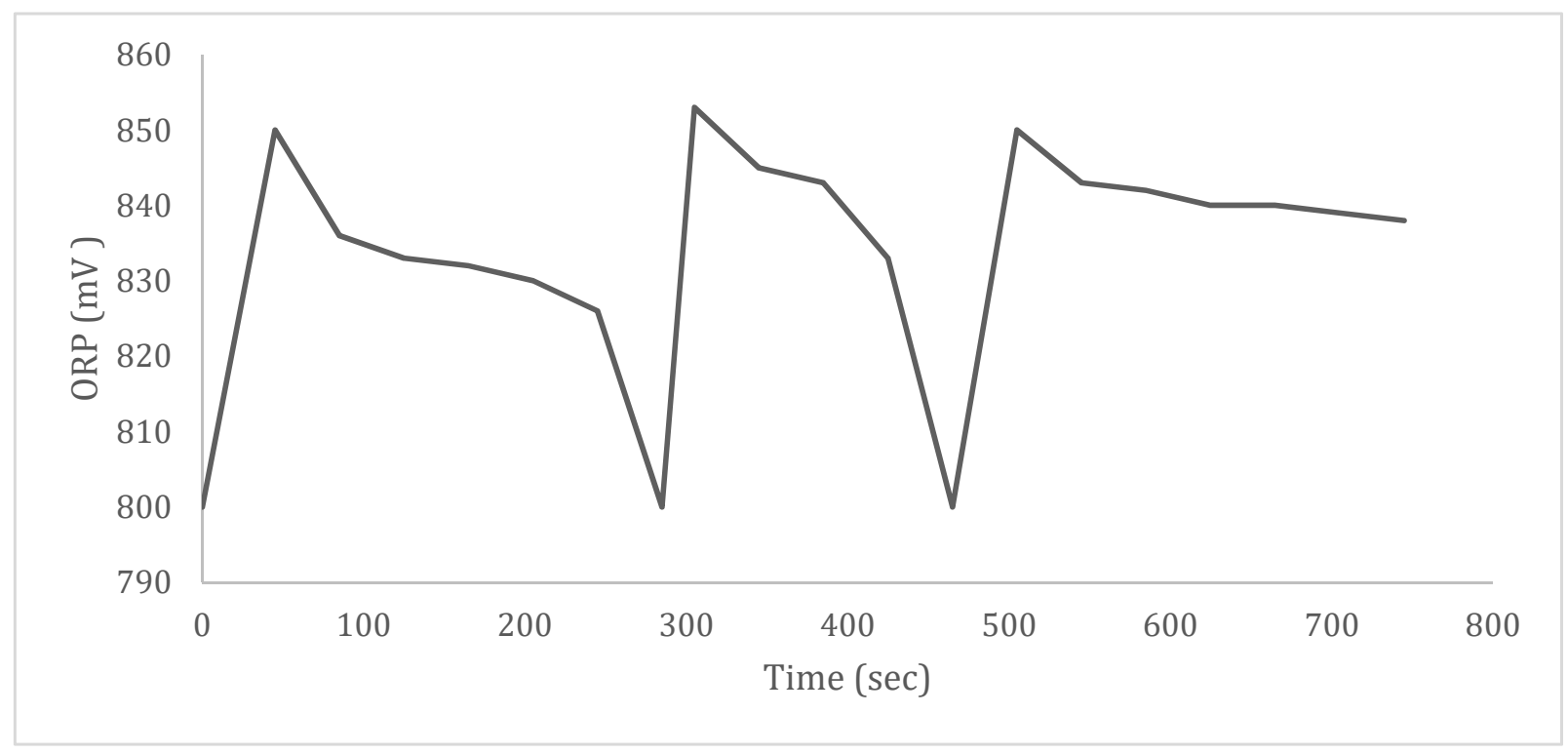

Figure 4. ORP change by starting and stopping ACD in closed-tube system.

\subsection{Clinical Verification}

3.5.1. Clinic On-Site Installation

The ACD dental chair set up in a dental clinic shown in Figure 5.

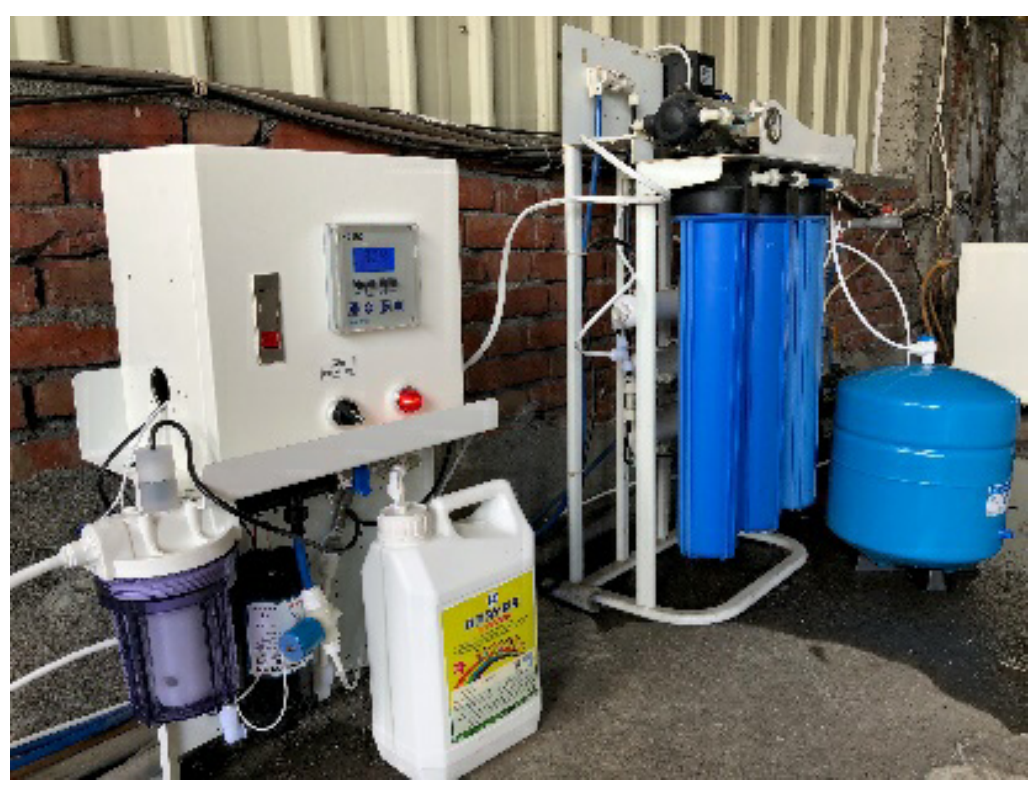

Figure 5. Fully installed water purification and disinfectant system.

\subsubsection{ORP Monitoring of Water System in Clinic}

The control system was set to start dosing at $800 \mathrm{mV}$ and stop dosing at $810 \mathrm{mV}$. The ORP was detected every $30 \mathrm{~s} /$ per time per record stored in the system storage device. In total, 13,080 records were collected and the ORP data were graphed as shown in Figure 6. The graph shows the actual experimental curve of water ORP monitored at 800 and $810 \mathrm{mV}$ in the ACD dental chair for five consecutive days. This evidence supports the notion that the device can control the water quality between $800-860 \mathrm{mV}$ at correctly predefined settings. 


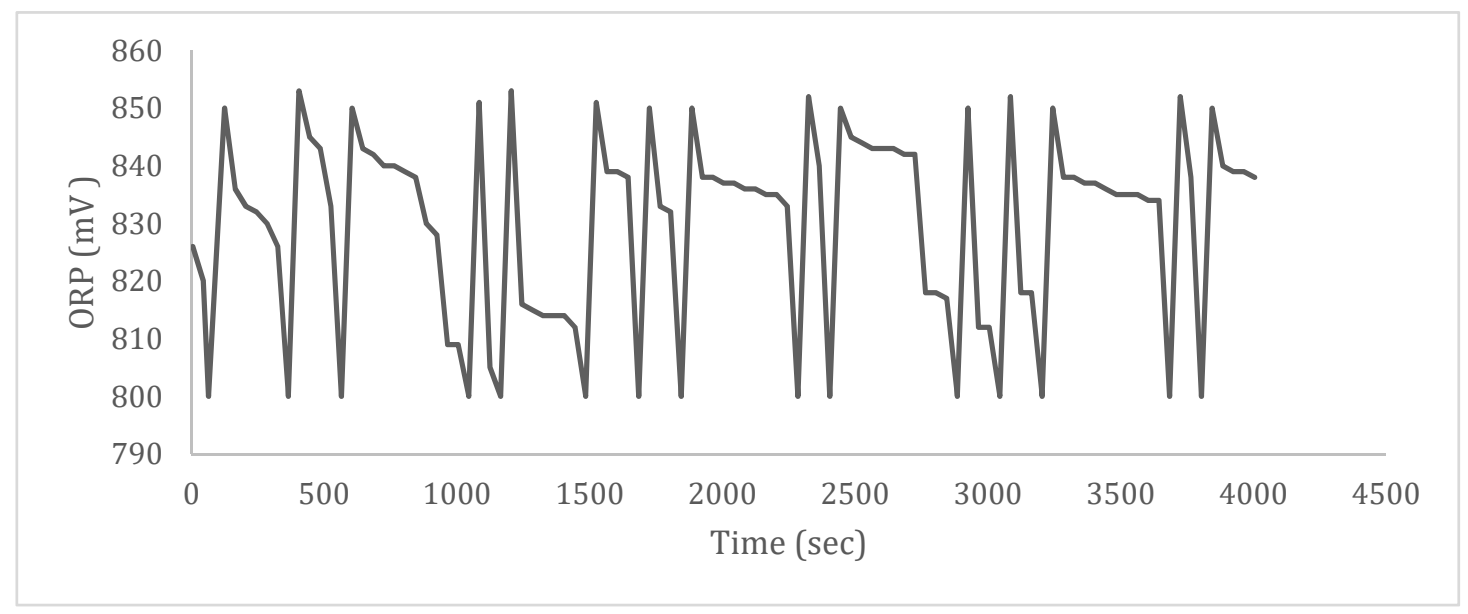

Figure 6. ORP change by starting and stopping ACD in water purification and disinfectant system for five consecutive days.

Manual ORP Detection of Water Quality at the Clinic System Outlet

The water effluent was collected for five consecutive days and manually measured using an ORP meter. The ORP value was controlled between 800-860 mV (Table 3).

Table 3. Stabilization of water ORP in dental clinic.

\begin{tabular}{cccccc}
\hline \multirow{2}{*}{$\begin{array}{c}\text { Sampling } \\
\text { Time/Date }\end{array}$} & $\mathbf{1}$ & $\mathbf{2}$ & $\mathbf{3}$ & $\mathbf{4}$ & $\mathbf{5}$ \\
\cline { 2 - 6 } & $\mathbf{6 / 3}$ & $\mathbf{6 / 4}$ & $\mathbf{6 / 5}$ & $\mathbf{6 / 6}$ & $\mathbf{6 / 7}$ \\
\hline 10:00 & 816 & 832 & 807 & - & 839 \\
$11: 00$ & 801 & 820 & 850 & - & 827 \\
$12: 00$ & 840 & 806 & 839 & - & 815 \\
$15: 00$ & 834 & 847 & 831 & 828 & 807 \\
$16: 00$ & 819 & 833 & 809 & 812 & 842 \\
$17: 00$ & 802 & 819 & 846 & 850 & 826 \\
18:00 & 845 & 803 & 833 & 840 & 809 \\
19:00 & 836 & 849 & 825 & 823 & 803 \\
$20: 00$ & 815 & 840 & 804 & 815 & 846 \\
$21: 00$ & 848 & 825 & 844 & 849 & 830
\end{tabular}

Note: -: clinic closed; 6/3-6/7, 2019, opening hours (morning-09:30-12:00; afternoon-14:30-18:00; evening-18:3021:30; $6 / 6$ (Thursday) closed in the morning, not sampled).

\section{Water Quality in the Dental Clinic}

Water samples were collected to determine the total bacterial colony counts and chlorite concentration (Table 4). The total bacteria count was less than $5 \mathrm{CFU} / \mathrm{mL}$. The chlorite concentration was less than $0.0004 \mathrm{mg} / \mathrm{L}$. Chloroxyanions, such as $\mathrm{ClO}_{2}{ }^{-}$(aq) or $\mathrm{ClO}_{3}{ }^{-}{ }_{\text {(aq) }}$, can be harmful to human health [20]. Drinking water regulations of Taiwan now require chlorite to be less than 0.7 ppm [21].

Table 4. Water quality in the dental clinic.

\begin{tabular}{cccc}
\hline Sample & Sampling Time & $\begin{array}{c}\text { Total Bacterial Colony } \\
\text { (CFU/mL) }\end{array}$ & $\begin{array}{c}\text { Chlorite } \\
(\mathbf{m g} / \mathrm{L})\end{array}$ \\
\hline 1 & 5 June 2019 08:50 & $<5$ & $<0.0004$ \\
2 & 5 June 2019 11:50 & $<5$ & $<0.0004$ \\
3 & 5 June 2019 15:00 & $<5$ & $<0.0004$ \\
4 & 10 June 2019 08:50 & $<5$ & $<0.0004$ \\
\hline
\end{tabular}

1. Before opening, 2. Noon before closing, 3. Open in the afternoon, 4. Before opening after a holiday (every two days). 


\subsection{Application of the ACD Dental Chair}

The ACD dental chair includes a dental treatment water purification and disinfectant system and clinic table (chair). The appropriate addition of the ACD can be used for disinfection of water, pipelines, and medical equipment. The ORP measures the oxidation disinfection rate caused by the addition of all the oxidants in the water. The ORP can be used as an indicator of bacterial inhibition. The higher the ORP, the stronger is the bactericidal power [22]. This study shows that $800-875 \mathrm{mV}$ can be obtained by maintaining a $\mathrm{ClO}_{2}$ concentration of $5-10 \mathrm{ppm}$ in the $\mathrm{RO}$ water system. Based on this information, the ORP was controlled between 800 and $860 \mathrm{mV}$. When the ORP was lower than $800 \mathrm{mV}$, the sensor detected it and informed the dosing device to adjust the ORP to $860 \mathrm{mV}$. Hence, the effective inhibitory concentration of $\mathrm{ClO}_{2}$ was maintained in the dental chair water.

The Centers for Disease Control and Prevention (CDC) of the United States and the American Dental Association (ADA) stipulate that the total number of bacterial colonies in drinking water should be below 500 [23] and $300 \mathrm{CFU} / \mathrm{mL}$ [24], respectively. The Sanitary Standard for Drinking Water (GB5749-2006) in China provides that the total bacterial colonies in drinking water does not exceed $500 \mathrm{CFU} / \mathrm{mL}$ [25]. Taiwan requires that the drinking water standard is below $100 \mathrm{CFU} / \mathrm{mL}$ [21]. In 2018 and 2019, 14 dental clinics installed water purification and disinfectant systems incorporating them into dental chairs, as shown in Figure 7. The ACD was added for dental chair water disinfection. The disinfection effects were examined before use (before installation) and after use (after installation). There were 11 dental clinics whose total colony count was higher than $500 \mathrm{CFU} / \mathrm{mL}$ before installation, so therefore did not meet the regulatory standards and needed to be improved. After installation, the total colony counts of the 14 clinics were all less than $5 \mathrm{CFU} / \mathrm{mL}$, in line with regulatory standards (Table 5). Figure 8 shows that the section of the pipeline before use is filled with biofilm (Figure 8a), and the section of the pipeline after use has no biofilm (Figure $8 \mathrm{~b}$ ). The chlorine dioxide produced by acidifying the sodium chlorite solution is corrosive due to the existence of excess acid. Chlorine dioxide will not hydrolyze in water to form acidic compounds. Thus, the ACD, pure chlorine dioxide in water, is not corrosive. Pure chlorine dioxide in water will not corrode stainless steel [26]. In our experience, the application of $4-5 \mathrm{ppm} \mathrm{ClO}_{2}$ to the pipes made of carbon, iron, polyvinyl chloride (PVC), and copper did not cause corrosion. For pipes made of stainless and PE were used in the ACD dental chair, no corrosion was observed.

Table 5. Comparison of total colony counts before and after water quality improvement in dental clinics.

\begin{tabular}{|c|c|c|c|c|}
\hline \multirow[b]{2}{*}{ Clinic Number } & \multicolumn{2}{|c|}{ Before System Improvement } & \multicolumn{2}{|c|}{ After System Improvement } \\
\hline & Sampling Time & $\begin{array}{c}\text { Total Number of } \\
\text { Colonies } \\
\text { (CFU/mL) }\end{array}$ & Sampling Time & $\begin{array}{c}\text { Total Number of } \\
\text { Colonies } \\
\text { (CFU/mL) }\end{array}$ \\
\hline 1 & 25 May 2018 & 1400 & 25 July 2018 & $<5$ \\
\hline 2 & 01 June 2018 & 1300 & 20 June 2018 & $<5$ \\
\hline 3 & 01 Aug. 2018 & 640 & 08 Aug. 2018 & $<5$ \\
\hline 4 & 07 Aug. 2018 & 1300 & 27 Aug. 2018 & $<5$ \\
\hline 5 & 10 Sep. 2018 & 510 & 06 Oct. 2018 & $<5$ \\
\hline 6 & 25 Jan. 2019 & 200 & 12 Apr. 2019 & $<5$ \\
\hline 7.1 & 22 July 2019 & 380 & 26 Aug. 2019 & $<5$ \\
\hline 7.2 & 22 July 2019 & 690 & 21 Aug. 2019 & $<5$ \\
\hline 8 & 22 July 2019 & 430 & 21 Aug. 2019 & $<5$ \\
\hline 9 & 22 July 2019 & 980 & 21 Aug. 2019 & $<5$ \\
\hline 10 & 29 July 2019 & 890 & 05 Aug. 2019 & $<5$ \\
\hline 11 & 26 Aug. 2019 & 1300 & 02 Sep. 2019 & $<5$ \\
\hline 12 & 26 Aug. 2019 & 1500 & 02 Sep. 2019 & $<5$ \\
\hline 13 & 26 Aug. 2019 & 1400 & 02 Sep. 2019 & $<5$ \\
\hline
\end{tabular}




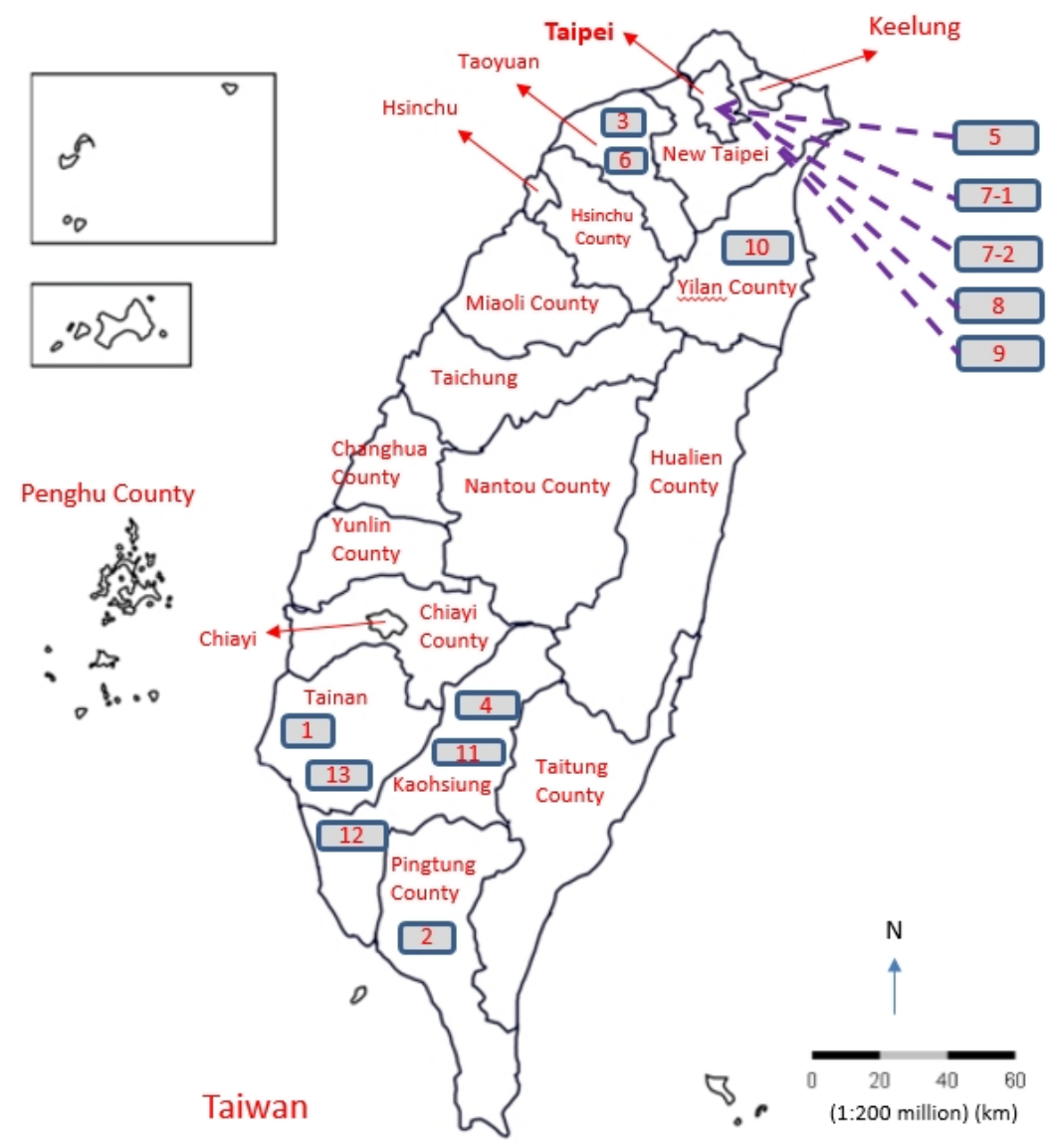

Figure 7. The locations of 14 dental clinics with installed ACD dental chairs in Taiwan.

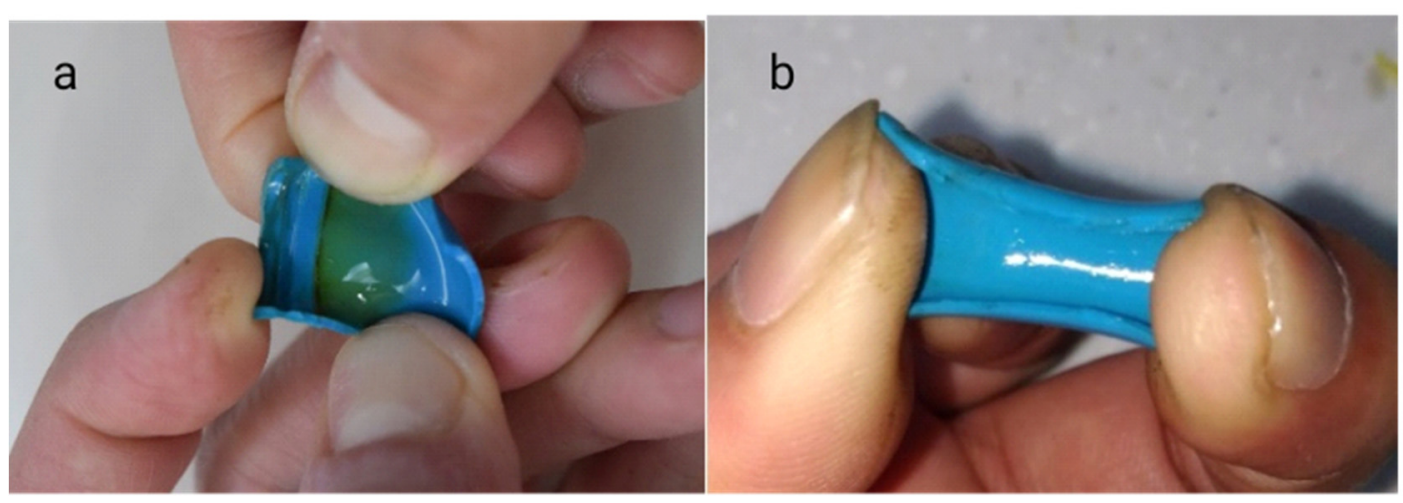

Figure 8. The ACD is added to RO water to clean the pipeline of the ACD dental chair. (a). The section of the pipeline before use is filled with biofilm. (b). The section of the pipeline after use has no biofilm.

\subsection{Future Study}

The efficacy and safety of injecting $\mathrm{ClO}_{2}$ in water systems to prevent hospital-acquired Legionnaires disease has been extensively evaluated $[27,28]$. After the $\mathrm{ClO}_{2}$ system was installed, a significant decrease in Legionella organisms was observed. However, an extended period of $\mathrm{ClO}_{2}$ exposure was needed to achieve this reduction. The delayed reduction in the rate of Legionella positivity is more likely caused by the low residual concentration of $\mathrm{ClO}_{2}$ in the hot water. Therefore, in order to achieve eradicating bacteria in water and to keep the water sterile, the effective $\mathrm{ClO}_{2}$ concentration must be maintained in the water body. In the future, the water purification and disinfectant system using ACD described herein should be further studied in hospital water systems. 


\section{Conclusions}

The gaseous $\mathrm{ClO}_{2}$ molecule is a highly active oxidizing molecule with excellent disinfection power. Compared with other disinfectants, ACD is highly safe to the human body and has a low impact on the environment. Therefore, ACD is an excellent disinfectant, but it has the disadvantage of not being easy to store, limiting its applicability. In order to expand the applicability of the ACD, we built an ACD device for use in real-life settings. Here, we studied the application of ACD to the dentist chair water supply system and investigated its related usage parameters.

When ACD is added to RO water, the ORP increases and the $\mathrm{pH}$ decreases. Above $25 \mathrm{ppm} \mathrm{ClO} 2$, the rate of increase in the ORP tends to slow down. Above $200 \mathrm{ppm} \mathrm{ClO}_{2}$, its $\mathrm{pH}$ value is 2.65 , which is highly acidic. The $\mathrm{pH}$ of $\mathrm{RO}$ water is approximately 6.0 at $25^{\circ} \mathrm{C}$. The ACD was controlled between 810 and $860 \mathrm{mV}$, which corresponds to 5-10 ppm of $\mathrm{ClO}_{2}$. The $\mathrm{pH}$ of 5-10 ppm $\mathrm{ClO}_{2}$ is 5.86-4.91, which is also a factor inhibiting the microorganism growth.

The ORP fluctuation and chlorine-like odor of ACD was investigated. The ORP of ACD has no chlorine-like odor below $860 \mathrm{mV}$ and the chlorine-like odor reappears at a ORP over $860 \mathrm{mV}$. Fourteen dental clinic chair systems were improved by incorporating the ACD dental chair. The ACD dental chair started dosing at $800 \mathrm{mV}$ and stopped dosing at $810 \mathrm{mV}$. The water ORP is controlled between 800 and $860 \mathrm{mV}$ by continuous monitoring and automatic dosing. The water solution was sampled and examined. Using our system on a dental chair water source, the total bacterial count of the water was less than $5 \mathrm{CFU} / \mathrm{mL}$ and the chlorite concentration was less than $0.0004 \mathrm{mg} / \mathrm{L}$, which meet the regulatory standards. Our ACD dental chair can effectively prevent microorganism growth when the solution ORP was controlled between 800 and $860 \mathrm{mV}$. The ACD dental chair was successfully used in dental treatment water quality systems as a closed-tube system. In the future, this ACD dental chair may also find use in the disinfection of closed pipelines used in the food, cosmetics, beverage, and animal husbandry industries.

Author Contributions: Conceptualization L.-L.W. and S.-S.W.; investigation, L.-L.W. and C.-C.H.; resources L.-L.W., S.-S.W., and C.-C.H.; formal analysis C.-W.H., C.-W.P., and L.-Y.C.; validation C.-C.H. and H.-C.Y.; data curation S.-S.W., Y.-C.Y., and J.R.C.; writing-original draft preparation, L.-L.W. and H.-C.Y.; writing-review and editing, Y.-C.Y., S.-S.W., and J.R.C.; funding acquisition L.-L.W. and C.-C.H., project administration L.-L.W. and H.-C.Y. All authors have read and agreed to the published version of the manuscript.

Funding: This research was funded by the Lian Medical Protection Equipment Co., Ltd., Project number LIAN202108SW001, Kaohsiung City, Taiwan, R.O.C.

Institutional Review Board Statement: Not Applicable.

Informed Consent Statement: Not Applicable.

Data Availability Statement: All data are available in the manuscript.

Acknowledgments: The author appreciate the help from the Lian Medical Protection Equipment Co., Ltd., Kaohsiung, Taiwan, ROC Guangdong ZD Aquatic Environmental Technology Co., Ltd., Guangdong, PRC, and Baihui Mercury Environmental Technology (Beijing) Co., Ltd., Beijing, PRC.

Conflicts of Interest: The authors declare no conflict of interest.

\section{Abbreviations}

ACD aqueous chlorine dioxide

ORP oxidation-reduction potential

$\mathrm{RO}$ reverse osmosis

$\mathrm{ClO}_{2}$ chlorine dioxide 


\section{References}

1. Spagnolo, A.M.; Sartini, M.; Cristina, M.L. Microbial Contamination of Dental Unit Waterlines and Potential Risk of Infection: A Narrative Review. Pathogens 2020, 9, 651. Available online: https://www.mdpi.com/2076-0817/9/8/651 (accessed on 5 October 2021). [CrossRef] [PubMed]

2. Kumar, S.; Atray, D.; Paiwal, D.; Balasubramanyam, G.; Duraiswamy, P.; Kulkarni, S. Dental unit waterlines: Source of contamination and cross-infection. J. Hosp. Infect. 2010, 74, 99-111. [CrossRef] [PubMed]

3. Szymańska, J.; Sitkowska, J.; Dutkiewicz, J. Microbial contamination of dental unit waterlines. Ann. Agric. Environ. Med. 2008, 15, 173-179. Available online: https:/ / pubmed.ncbi.nlm.nih.gov/19061251/ (accessed on 5 October 2021). [PubMed]

4. Ji, X.Y.; Fei, C.N.; Zhang, Y.; Liu, J.; Liu, H.; Song, J. Three key factors influencing the bacterial contamination of dental unit waterlines: A 6-year survey from 2012 to 2017. Int. Dent. J. 2019, 69, 192-199. [CrossRef] [PubMed]

5. Reregistration Eligibility Decision (RED) for Chlorine Dioxide and Sodium Chlorite (Case 4023). In US EPA 738-R-06-007; 2006; pp. 3-4. Available online: https://www3.epa.gov/pesticides/chem_search/reg_actions/reregistration/red_PC-020503_3-Aug06.pdf (accessed on 6 October 2021).

6. Chlorine Dioxide Gas. In Concise International Chemical Assessment Document 37; World Health Organization: Geneva, Switzerland, 2002; Volume 7. Available online: https://www.who.int/ipcs/publications/cicad/en/cicad37.pdf (accessed on 6 October 2021).

7. Kaly-Kullai, K.; Wittmann, M.; Noszticzius, Z.; Rosivall, L. Can chlorine dioxide prevent the spreading of coronavirus or other viral infections? Medical hypotheses. AK J. Physiol. Int. 2020, 107, 1-11. [CrossRef] [PubMed]

8. Zhu, Z.; Guo, Y.; Yu, P.; Wang, X.; Zhang, X.; Dong, W.; Liu, X.; Guo, C. Chlorine dioxide inhibits the replication of porcine reproductive and respiratory syndrome virus by blocking viral attachment. Infect. Genet. Evol. 2019, 67, 78-87. [CrossRef] [PubMed]

9. Zoni, R.; Zanelli, R.; Riboldi, E.; Bigliardi, L.; Sansebastiano, G. Investigation on virucidal activity of chlorine dioxide. experimental data on feline calicivirus, HAV and Coxsackie B5. J. Prev. Med. Hyg. 2007, 48, 91-95. [CrossRef] [PubMed]

10. Ma, J.W.; Huang, B.S.; Hsu, C.W.; Peng, C.W.; Cheng, M.L.; Kao, J.Y.; Way, T.D.; Yin, H.C.; Wang, S.S. Efficacy and Safety Evaluation of a chlorine dioxide solution. Int. J. of Environ. Res. and Public Health. 2017, 14, 329. [CrossRef] [PubMed]

11. Liu, X.; Jiao, W.; Du, Y.; Chen, Q.; Su, Z.; Fu, M. Chlorine Dioxide Controls Green Mold Caused by Penicillium digitatum in Citrus Fruits and the Mechanism Involved. J. Agric. Food Chem. 2020, 68, 13897-13905. [CrossRef] [PubMed]

12. Sanekata, T.; Fukuda, T.; Miura, T.; Morino, H.; Lee, C.; Maeda, K.; Araki, K.; Otake, T.; Kawahata, T.; Shibata, T. Evaluation of the antiviral activity of chlorine dioxide and sodium hypochlorite against feline calicivirus, human influenza virus, measles virus, canine distemper virus, human herpesvirus, human adenovirus, canine adenovirus and canine parvovirus. Biocontrol. Sci. 2010, 15, 45-49. [CrossRef] [PubMed]

13. Lubbers, J.R.; Chauhan, S.; Miller, J.K.; Bianchine, J.R. The effects of chronic administration of chlorine dioxide, chlorite and chlorate to normal healthy adult male volunteers. J. Environ. Pathol. Toxicol. Oncol. 1984, 5, 229-238. Available online: https:/ / pubmed.ncbi.nlm.nih.gov / 6520728 / (accessed on 9 October 2021). [PubMed]

14. Lubbers, J.R.; Bianchine, J.R. Effects of the acute rising dose administration of chlorine dioxide, chlorate and chlorite to normal healthy adult male volunteers. J. Environ. Pathol. Toxicol. Oncol. 1984, 5, 215-228. Available online: https://pubmed.ncbi.nlm.nih. gov/6520727/ (accessed on 10 October 2021). [PubMed]

15. Lubbers, J.R.; Chauhan, S.; Bianchine, J.R. Controlled clinical evaluations of chlorine dioxide, chlorite and chlorate in man. Fundam. Appl. Toxicol. 1981, 1, 334-338. [CrossRef]

16. Jang, A.; Szabo, J.; Hosni, A.A.; Coughlin, M.; Bishop, P.L. Measurement of chlorine dioxide penetration in dairy process pipe biofilms during disinfection. Appl. Microbiol. Biotechnol. 2006, 72, 368-376. [CrossRef] [PubMed]

17. Gagnon, G.A.; Rand, J.L.; O'leary, K.C.; Rygel, A.C.; Chauret, C.; Andrews, R.C. Disinfectant efficacy of chlorite and chlorine dioxide in drinking water biofilms. Water Res. 2005, 39, 1809-1817. [CrossRef] [PubMed]

18. Nam, H.; Seo, H.S.; Bang, J.; Kim, H.; Beuchat, L.R.; Ryu, J.H. Efficacy of gaseous chlorine dioxide in inactivating Bacillus cereus spores attached to and in a biofilm on stainless steel. Int. J. Food Microbiol. 2014, 188, 122-127. [CrossRef] [PubMed]

19. Wagner, H.P.; Pepich, B.V.; Hautman, D.P.; Munch, D.J.; Salhi, E. Method 326.0 Determination of Inorganic Oxyhalide Disinfection By-Products in Drinking Water Using Ion Chromotography Incorporating the Addition of a Suppressor Acidified Postcolumn Reagent for Trace Bromate Analysis. Desalination 2008, 224, 231-239. Available online: https:/ / www.researchgate.net/publication/222557829_Determination_of_inorganic_oxyhalide_disinfection_by-products_in_ bottled_water_by_EPA_Method_3260_for_trace_bromate_analysis (accessed on 13 October 2021).

20. Chlorite and Chlorate in Drinking-water. In WHO/SDE/WSH/05.08/86; World Health Organization: Geneva, Switzerland, 2005; Available online: https://www.who.int/water_sanitation_health/dwq/chemicals/chlorateandchlorite0505.pdf (accessed on 14 October 2021).

21. Drinking Water Quality Standards. In Agricultural Environmental Protection; Executive Yuan Bulletin: Taipei, Taiwan, 2017; Volume 23, p. 6. Available online: https://gazette.nat.gov.tw/EG_FileManager/eguploadpub/eg023006/ch07/type1/gov60/ num29/OEg.pdf (accessed on 15 October 2021).

22. Oxidation-Reduction Potential. Fact Sheets. In Environmental Health; 2016. Available online: https://www.health.nsw.gov.au/ environment/factsheets/Pages/orp.aspx (accessed on 5 October 2021). 
23. Kohn, W.G.; Collins, A.S.; Cleveland, J.L.; Harte, J.A.; Eklund, K.J.; Malvitz, D.M.; Centers for Disease Control and Prevention (CDC). Guidelines for infection control in dental health-care settings-2003. MMWR Recomm. Rep. 2003, 52, 1-61. Available online: https:/ / pubmed.ncbi.nlm.nih.gov/14685139/ (accessed on 18 October 2021). [PubMed]

24. Dental Unit Waterlines. Oral Health Topics; American Dental Association: Chicago, IL, USA, 2019. Available online: https: //www.ada.org/en/member-center/oral-health-topics/dental-unit-waterlines (accessed on 13 October 2021).

25. Standards for drinking water quality. GB 5749-2006. In National Standards of the People's Republic of China; Ministry of Health: Beijing, China, 2006. Available online: http:/ / tradechina.dairyaustralia.com.au/wp-content/uploads/2018/08/GB-5749-2006Standards-for-Drinking-Water-Quality.pdf (accessed on 15 October 2021).

26. Material Compatibility. ClorDiSys. 2014. Available online: https://www.clordisys.com/materialcompatibility.php (accessed on 19 October 2021).

27. Sidari, F.P.; Stout, J.E.; Van Briesen, J.M.; Bowman, A.M.; Grubb, D.; Neuner, A.; Wagener, M.M.; Yu, V.L. Keeping Legionella out of water systems. J. Am. Water Works Assoc. 2004, 96, 111-119. [CrossRef]

28. Zhang, Z.; McCann, C.; Stout, J.E.; Piesczynski, S.; Hawks, R.; Vidic, R.; Yu, V.L. Safety and Efficacy of Chlorine Dioxide for Legionella Control in a Hospital Water System. Infect. Control Hospital Epidemiol. 2007, 28, 1009-1012. [CrossRef] [PubMed] 